\section{Plant Nutrition Requirements for an Installed Sedum-Vegetated Green Roof Module System: Effects of Fertilizer Rate and Type on Plant Growth and Leachate Nutrient Content}

\author{
Mary Jane Clark and Youbin Zheng ${ }^{1}$ \\ School of Environmental Sciences, University of Guelph, 50 Stone Road East, \\ Guelph, Ontario, N1G 2W1, Canada; and Vineland Research and Innovation \\ Centre, 4890 Victoria Avenue North, Box 4000, Vineland Station, Ontario, \\ LOR 2E0, Canada
}

Additional index words. controlled-release fertilizer, green roof maintenance, living roof, mineral nutrition, nutrient runoff

\begin{abstract}
The objectives of this study were to compare fertilizer rates and types to identify an optimum rate to maintain green roof vegetative coverage and encourage plant growth (i.e., plant performance) while minimizing the amount and concentration of nutrients leached from a green roof module system. Sedum-vegetated modules with no added fertilizer (control) were compared with modules fertilized with $5,7.5,10,15,20,30$, and $60 \mathrm{~g} \cdot \mathrm{m}^{-2}$ nitrogen $(\mathrm{N})$ of $16 \mathrm{~N}-2.6 \mathrm{P}-10 \mathrm{~K}$ POLYON ${ }^{\circledR}$ Homogenous NPK plus Minors, 5-6 month controlled-release fertilizer (CRF), $5 \mathrm{~g} \cdot \mathrm{m}^{-2} \mathrm{~N}$ of a $2.9 \mathrm{~N}-2.2 \mathrm{P}-2.3 \mathrm{~K}$ fly-larvae processed chicken manure fertilizer (5-Sus), or $5 \mathrm{~g} \cdot \mathrm{m}^{-2} \mathrm{~N}$ of $4 \mathrm{~N}-4 \mathrm{P}-4 \mathrm{~K}$ Gaia Green All Purpose organic fertilizer (5-OR). The total amount and concentration of aluminum (AI), calcium (Ca), cadmium (Cd), chromium (Cr), copper (Cu), iron (Fe), mercury (Hg), potassium $(\mathrm{K})$, magnesium $(\mathrm{Mg})$, sodium $(\mathrm{Na}), \mathrm{NH}_{4}^{+}$, nickel $(\mathrm{Ni}), \mathrm{NO}_{3}^{-}$, phosphorus $(\mathrm{P})$, lead $(\mathrm{Pb})$, sulfur $(\mathrm{S})$, and zinc $(\mathrm{Zn})$ in leachate as well as plant overall appearance, winter injury, vegetative coverage, shoot height, bloom duration, and leaf color of green roof modules were evaluated between July 2011 and Aug. 2012. A CRF fertilizer rate of 15 $\mathrm{g} \cdot \mathrm{m}^{-2} \mathrm{~N}$ maximized vegetative coverage and overall plant appearance while maintaining leachate quality within Ontario and Canadian guidelines for most of the measured elements. The amount of $\mathrm{Zn}$ in the $\mathrm{CRF}$ appeared to be higher than plant demand and the high amount and concentration of $P$ in leachate was likely the result of release from the growing substrate. The 5-Sus fertilizer resulted in increased coverage the first spring and increased greenness soon after application compared with the same rate of CRF. Overall, $15 \mathrm{~g} \cdot \mathrm{m}^{-2} \mathrm{~N}$ of CRF was the best treatment based on vegetative coverage and plant growth in sedum-vegetated green roof modules.
\end{abstract}

Currently, green roof installations are being widely planted to provide environmental, economic, and aesthetic benefits (Czemiel Berndtsson, 2010; Oberndorfer et al., 2007). Widespread implementation of green roof technology has been seen in North America recently with the area of green roof installations increasing by $115 \%$ in 2011 compared with 2010 (Green Roofs for Healthy Cities,

\footnotetext{
Received for publication 13 May 2013. Accepted for publication 30 July 2013.

This work was financially supported by the Ontario Ministry of Agriculture, Food and Rural Affairs/ University of Guelph Research Program, Landscape Ontario, LiveRoof $^{\circledR}$ Ontario Inc., Sedum Master, and Carrot Common.

We thank LiveRoof ${ }^{\circledR}$ Ontario Inc. for providing the plant material and Greg Yuristy, Katherine Vinson, Linping Wang, Mohammad Eftekhar, Thannushan Nimalendra, Arlin Otto, and Siobhan Dunets for their technical assistance.

${ }^{1}$ To whom reprint requests should be addressed; e-mail yzheng@uoguelph.ca.
}

2012). Green roof plants greatly contribute to green roof benefits (Dunnett and Kingsbury, 2008; Morgan et al., 2012); however, few studies evaluate growing environment factors (i.e., substrate fertility), which influence green roof plant performance and environmental impacts (Emilsson et al., 2007; Rowe et al., 2006). Therefore, recommendations are needed for green roof installations and maintenance that optimize plant performance and minimize the environmental impact of green roofs.

Fertilization can influence plant performance and green roof environmental impact. With appropriate root zone fertility and $\mathrm{pH}$ ranges, plants can remain healthy (Jones, 2012; Zheng and Clark, 2013). In conditions of low or high fertility, or when $\mathrm{pH}$ is outside an optimal range, stress conditions can contribute to minimal or excess plant growth, resulting in plant dieback, especially during cold winter weather (Barker and Lubell, 2012; Clark and Zheng, 2012; Zheng and Clark, 2013). In addition, overfertilization can result in plant toxicity (Chen et al., 2001) and nutrient leaching to the environment. The amount of nutrients, provided by both the fertilizer and growing substrate, needs to meet but not exceed plant demand to prevent nutrient leaching from green roofs (Clark and Zheng, 2012; Czemiel Berndtsson, 2010; Gregoire and Clausen, 2011; Retzlaff et al., 2008). Climactic factors such as precipitation and temperature also influence nutrient availability and leaching from the growing environment and need to be considered when developing recommendations. Green roof maintenance recommendations are needed to identify balanced growing substrate fertility levels that meet but do not exceed plant requirements.

Plant performance impacts green roof functioning and is evaluated by plant survival, establishment, growth, and vegetative coverage (Clark and Zheng, 2012; Emilsson et al., 2007; FLL, 2008; Retzlaff et al., 2009; Zheng and Clark, 2013). Plant establishment impacts green roof plant growth and biomass, which contribute to green roof environmental benefits (Rowe, 2011; Tan and Sia, 2009; Wolf and Lundholm, 2008). Green roof performance is also influenced by vegetation coverage, as shown through modeling (Currie and Bass, 2008; Sailor, 2008). Thus, optimizing plant performance through appropriate maintenance recommendations will contribute to optimal green roof functions.

A negative environmental impact from green roofs (i.e., nutrient leaching) can be influenced by the fertility of both the growing substrate and applied fertilizer (Czemiel Berndtsson, 2010; Gregoire and Clausen, 2011; Retzlaff et al., 2008). Surface and groundwater quality guidelines have been developed in Ontario (MOEE, 1994) and Canada (CCME, 2012) for protection of aquatic life and recreation. Green roof runoff is not governed by these regulations; however, the guidelines can act as a target for green roof runoff quality and environmental impact (Van Seters et al., 2009). Thus, green roof maintenance recommendations need to suggest appropriate fertilizer application rates to avoid negative environmental impacts from nutrient leaching.

Recommendations currently suggest fertilizing green roofs at a rate based on the substrate fertility (FLL, 2008) or annually with $5 \mathrm{~g} \cdot \mathrm{m}^{-2} \mathrm{~N}$ beginning in the second year after installation (Snodgrass and Snodgrass, 2006). It is assumed that green roof plant nutrition requirements are supplied by the growing substrate during establishment (Snodgrass and Snodgrass, 2006) or that if fertilizer is applied at installation, an attempt is made to reduce nutrient leaching (FLL, 2008). The growing substrate composition, roof age, and fertilizer type contribute to nutrient leaching with higher nutrient loss from young vs. old green roofs (Van Seters et al., 2009), substrates containing high vs. low proportions of compost or organic matter (Moran, 2004; Rowe et al., 2006), and from conventional vs. CRF applications (Emilsson et al., 2007). Although commercial green roof substrates vary in their capacity to leach nutrients (Van Seters et al., 2009), on-roof studies are needed 
to evaluate nutrient leaching, especially for young and newly installed green roofs. For young green roof installations, a range of fertilizer rates need to be tested for plant performance vs. performance when grown with nutrition supplied by the growing substrate alone. The present study built on work by Clark and Zheng (2012) and Van Seters et al. (2009) by evaluating nutrient leaching from green roof modules after an on-roof installation.

Fertilization using CRFs is recommended to meet nutrition needs of green roof plants (Snodgrass and Snodgrass, 2006); however, more economical fertilizer types such as conventional granular fertilizers (Emilsson et al., 2007; Retzlaff et al., 2008) have been studied. As a result of the fast nutrient release of conventional fertilizers, more nutrients are leached from a green roof fertilized with conventional fertilizers vs. CRFs (Emilsson et al., 2007). Other green roof fertilizer types gaining popularity are organic and sustainable fertilizers; however, no green roof studies have reported plant performance and nutrient leaching after fertilization with these types. Therefore, this study will expand on previous work by evaluating the effect of $\mathrm{CRF}$, organic, and sustainable fertilizers, applied after installation, on sedum-vegetated green roof modules. Specifically, the objectives of this study were to compare fertilizer rates and types to identify optimum rates to maintain green roof vegetative coverage and encourage plant growth (i.e., plant performance) while minimizing the amount of nutrients leached from a green roof module system.

\section{Materials and Methods}

\section{Plant material and treatments}

Green roof modules were produced by LiveRoof $^{\circledR}$ Ontario Inc. (Mount Brydges, Ontario, Canada) under standard field production conditions. Modules measured 30.5 $\mathrm{cm} \times 61.0 \mathrm{~cm}$ and were filled to a depth of $10.2 \mathrm{~cm}$ with standard LiveRoof ${ }^{\circledR}$ substrate [comprised of aggregate components, $6.8 \%$ $\mathrm{w} / \mathrm{w}$ dry organic matter, $10.2 \%$ air-filled porosity, $0.93 \mathrm{~g} \cdot \mathrm{cm}^{-2}$ dry bulk density, electrical conductivity (EC) of $761 \mu \mathrm{S} \cdot \mathrm{cm}^{-1}$, and
$\mathrm{pH}$ of 6.5], which was held in the trays by white plastic raisers. The substrate had a $42 \%$ volumetric water content, $0.013 \mathrm{~cm} \cdot \mathrm{s}^{-1}$ permeability factor, contained $203.8 \mathrm{mg} \cdot \mathrm{kg}^{-1}$ total $\mathrm{N}$ (i.e., total Kjeldahl $\mathrm{N}$ determined using a classical Kjeldahl digestion and a Skalar segmented flow autoanalyzer and $\mathrm{NO}_{3}{ }^{-}$ determined using ion chromatography by SGS Agri-Food Laboratories, Guelph, Ontario, Canada), $180.0 \mathrm{mg} \cdot \mathrm{kg}^{-1}$ total $\mathrm{P}$, and 930.0 $\mathrm{mg} \cdot \mathrm{kg}^{-1}$ total $\mathrm{K}$ (analyzed using a borate fusion-internal standard and X-ray fluorescence spectrometry method by SGS Laboratories, Lakefield, Ontario, Canada). The plantavailable nutrient composition of the substrate was $2.00 \mathrm{mg} \cdot \mathrm{kg}^{-1} \mathrm{NO}_{3}^{-}$, less than $1 \mathrm{mg} \cdot \mathrm{kg}^{-1} \mathrm{P}$, and $46.13 \mathrm{mg} \cdot \mathrm{kg}^{-1} \mathrm{~K}$ (analyzed using a saturated paste extraction method by SGS Agri-Food Laboratories). Each module was planted with a mix of cuttings from the following Sedum spp.: S. ellacombianum Praeger, $S$. reflexum L. 'Blue Spruce', $S$. rupestre L. 'Angelina', S. selskianum Regel \& Maack 'Goldilocks', and S. spurium Bieb. cvs. On 21 July 2010, modules were shipped and installed on the fifth floor roof of the Science Complex at the University of Guelph (lat. 43 $31^{\prime} 49^{\prime \prime} \mathrm{N}$, long. $\left.80^{\circ} 13^{\prime} 44^{\prime \prime} \mathrm{W}\right)$. Modules were watered with raw water once per week for the first week, twice per week for the second week, and as needed, approximately once or twice per month, during the growing season.

On 15 July 2011, almost 1 year after installation, the current study began by applying the following fertilizer treatments to the modules as outlined in Table 1: $16 \mathrm{~N}-$ 2.6P-10K POLYON ${ }^{\circledR}$ Homogenous NPK plus Minors, 5-6 month controlled-release fertilizer (Agrium Advanced Technologies, Brantford, Ontario, Canada) applied at 0, 5, $7.5,10,15,20,30$, or $60 \mathrm{~g} \cdot \mathrm{m}^{-2} \mathrm{~N}$ (further described as the control, 5, 7.5, 10, 15, 20, 30, and 60 treatments) as well as $5 \mathrm{~g} \cdot \mathrm{m}^{-2} \mathrm{~N}$ of a $2.9 \mathrm{~N}-2.2 \mathrm{P}-2.3 \mathrm{~K}$ fly-larvae processed chicken manure sustainable fertilizer (5-Sus; University of Guelph, Guelph, Ontario, Canada) or $5 \mathrm{~g} \cdot \mathrm{m}^{-2} \mathrm{~N}$ of an organic fertilizer $(5-\mathrm{OR} ; 4 \mathrm{~N}$ 4P-4K Gaia Green All Purpose organic fertilizer; Gaia Green Products Ltd., Grand Forks, British Columbia, Canada). For 5-Sus and 5-OR, half of the amount $\left(2.5 \mathrm{~g} \cdot \mathrm{m}^{-2} \mathrm{~N}\right)$ was applied at each of two application times during the growing season to produce a similar nutrient availability to the $5 \mathrm{CRF}$ treatment and reduce the potential for nutrient leaching. The 5-Sus was applied on 15 July and 7 Sept. 2011, and 5-OR was applied on 26 Aug. and 26 Sept. 2011 as a result of product availability. Fertilizer was applied by spreading the granules evenly over each module by hand, the plant stems were brushed by hand to settle any fertilizer held in the plant canopy, and the plants were watered by hand with reverse osmosis (RO) water to wash off fertilizer that rested on the leaves. Supplemental RO water was applied by hand weekly, or as needed, to maintain plant health. Eight and seven rain events produced leachate from modules, averaging 3.6 L and $3.2 \mathrm{~L}$ of precipitation per module between 25 Aug. and 28 Oct. 2011 and 13 Mar. and 7 Aug. 2012, respectively. Each of the 10 fertilizer treatments was replicated three times and installed in a completely randomized design with two touching rows of 15 modules per row, ensuring each module had only one exposed side. Two modules were placed at the end of each row as borders to reduce edge effects. Each module was positioned on top of a leachate-collection tray, and a plastic strip was secured around the tray to eliminate ambient rain or irrigation water from entering the tray. The leachatecollection trays were made by lining a standard LiveRoof ${ }^{\circledR}$ module with a thick plastic sheet. Foam blocks were secured on the plastic in the trays to elevate the planted modules and allow excess water to drain from the planted module into the tray. Trays were removed during the winter, and the modules were placed directly on the roof to reduce potential cold stress resulting from elevation above the roof surface. During the study, mean monthly air temperature ranged from 22.7 to $-2.9^{\circ} \mathrm{C}$ in July and Jan. 2012, respectively.

\section{Measurements}

Throughout the 2011 and 2012 growing seasons, root zone $\mathrm{pH}$ and EC levels were monitored monthly by evaluating leachate characteristics. Leachate was acquired by

Table 1. Plant winter injury, overall appearance, and bloom duration for green roof modules grown under different fertilization rates and types.

\begin{tabular}{|c|c|c|c|c|c|c|c|c|c|c|}
\hline \multirow[b]{2}{*}{ Treatment } & \multicolumn{3}{|c|}{ Rate $\left(\mathrm{g} \cdot \mathrm{m}^{-2}\right)^{\mathrm{z}}$} & \multirow[b]{2}{*}{ Winter injury ${ }^{\mathrm{y}}$} & \multicolumn{4}{|c|}{2012 overall appearance ${ }^{x}$} & \multicolumn{2}{|c|}{ Bloom duration (days) $^{\mathrm{w}}$} \\
\hline & Nitrogen & Phosphorus & $\overline{\text { Potassium }}$ & & March & May & June & July & All species & S. spurium \\
\hline Control & 0.0 & 0.0 & 0.0 & $1.0 \mathrm{c}$ & $5.0 \mathrm{e}$ & $5.0 \mathrm{~d}$ & $5.0 \mathrm{c}$ & $5.0 \mathrm{~d}$ & $29.3 \pm 11.3$ & $7.7 \pm 7.7$ \\
\hline 5 & 5.0 & 0.8 & 3.1 & $1.0 \mathrm{c}$ & $4.3 \mathrm{~d}$ & $4.7 \mathrm{~cd}$ & $5.0 \mathrm{c}$ & $4.3 \mathrm{~cd}$ & $49.7 \pm 7.5$ & $17.7 \pm 13.4$ \\
\hline 7.5 & 7.5 & 1.2 & 4.7 & $1.0 \mathrm{c}$ & $3.0 \mathrm{abcd}$ & $2.3 \mathrm{abc}$ & $2.3 \mathrm{ab}$ & $2.3 \mathrm{ab}$ & $51.0 \pm 11.9$ & $34.3 \pm 12.6$ \\
\hline 10 & 10.0 & 1.6 & 6.2 & $2.0 \mathrm{c}$ & $2.3 \mathrm{abc}$ & $3.0 \mathrm{abc}$ & $3.7 \mathrm{bc}$ & $3.3 \mathrm{bcd}$ & $54.3 \pm 13.9$ & $40.0 \pm 4.4$ \\
\hline 15 & 15.0 & 2.5 & 9.3 & $1.7 \mathrm{c}$ & $2.3 \mathrm{abc}$ & $2.0 \mathrm{ab}$ & $1.0 \mathrm{a}$ & $1.3 \mathrm{a}$ & $44.3 \pm 2.0$ & $31.0 \pm 13.7$ \\
\hline 20 & 20.0 & 3.3 & 12.5 & $2.0 \mathrm{c}$ & $2.0 \mathrm{ab}$ & $1.0 \mathrm{a}$ & $1.7 \mathrm{a}$ & $1.3 \mathrm{a}$ & $64.0 \pm 3.0$ & $37.0 \pm 7.6$ \\
\hline 30 & 30.0 & 4.9 & 18.7 & $2.7 \mathrm{~b}$ & $1.3 \mathrm{a}$ & $2.3 \mathrm{abc}$ & $1.7 \mathrm{a}$ & $2.6 \mathrm{abc}$ & $58.3 \pm 11.6$ & $36.3 \pm 9.4$ \\
\hline 60 & 60.0 & 9.8 & 37.4 & $4.7 \mathrm{a}$ & $3.7 \mathrm{bcd}$ & $1.7 \mathrm{ab}$ & $1.7 \mathrm{a}$ & $3.6 \mathrm{bcd}$ & $42.3 \pm 6.9$ & $32.7 \pm 2.4$ \\
\hline 5-OR & 5.0 & 2.2 & 4.2 & $1.0 \mathrm{c}$ & $4.0 \mathrm{~cd}$ & $4.0 \mathrm{~cd}$ & $4.3 \mathrm{c}$ & $3.6 \mathrm{bcd}$ & $62.7 \pm 5.7$ & $25.3 \pm 11.0$ \\
\hline 5-Sus & 5.0 & 3.7 & 3.8 & $1.0 \mathrm{c}$ & $3.0 \mathrm{abcd}$ & $4.0 \mathrm{~cd}$ & $4.0 \mathrm{bc}$ & $3.6 \mathrm{bcd}$ & $37.7 \pm 20.9$ & $18.3 \pm 12.0$ \\
\hline
\end{tabular}

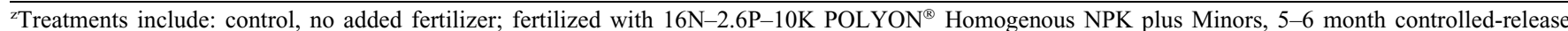
fertilizer at rates of $5,7.5,10,15,20,30$, and $60 \mathrm{~g} \cdot \mathrm{m}^{-2}$ nitrogen $(\mathrm{N}) ; 4 \mathrm{~N}-4 \mathrm{P}-4 \mathrm{~K}$ Gaia Green All Purpose organic fertilizer $\left(5-\mathrm{OR}, 5 \mathrm{~g} \cdot \mathrm{m}^{-2} \mathrm{~N}\right)$; or $2.9 \mathrm{~N}-2.2 \mathrm{P}-2.3 \mathrm{~K}$ fly-larvae processed chicken manure $\left(5-\mathrm{Sus}, 5 \mathrm{~g} \cdot \mathrm{m}^{-2} \mathrm{~N}\right)$.

${ }^{y}$ Ranked on a scale of 1 (least) to 5 (most) leaf desiccation damage; data are means of three replicates.

${ }^{\mathrm{x}}$ Ranked on a scale of 1 (most) to 5 (least) appealing; data are means of three replicates.

${ }^{\mathrm{w}}$ Mean of three replications per treatment \pm SE. Means in the same column followed by the same letter are not significantly different at $P \leq 0.05$ according to Tukey's multiple comparison test. 
conducting a pour-through analysis modeled after the method by Wright (1986) using $1 \mathrm{~L}$ of RO water applied per module in one dose by hand. Collected leachate was evaluated for $\mathrm{pH}$ and $\mathrm{EC}$ using a portable $\mathrm{pH}$ and $\mathrm{EC}$ meter (Oakton PC 300; Oakton Instruments, Vernon Hills, IL). After pour-through analysis and after rain events, total leachate volume was measured, and a subsample was stored at $-80{ }^{\circ} \mathrm{C}$. At the end of the study, volumeweighted aliquots per subsample were combined in one container, mixed by stirring, and subsampled before elemental analysis was conducted using a Varian Vista Pro ICP-OES with an axially viewed plasma (Varian Inc., Australia). Total nutrient loss $\left(\mathrm{N}_{\text {Loss }}\right)$ was calculated using the total leachate volume captured during the study $\left(\mathrm{V}_{\text {tot }}\right)$ and the volume-weighted nutrient concentration $\left(\mathrm{N}_{\mathrm{c}}\right)$ by the following equation: $\mathrm{N}_{\text {Loss }}=\mathrm{V}_{\text {tot }} \cdot \mathrm{N}_{\mathrm{c}}$.

The response of Sedum plant growth to fertilizer treatments was evaluated in four areas: winter injury and overall appearance, vegetative coverage, plant growth and flowering, and leaf color. Winter injury was measured for each module by visually estimating the percent of shoots per Sedum spp. showing leaf desiccation in the spring (i.e., Mar. 2012). Overall module appearance was rated relative to all other modules and based on plant growth, color, visual appeal, and perceived plant health. Vegetative coverage per module was visually estimated by comparing vegetation-covered with non-covered areas for both the proportion coverage per sedum species and of the module as a whole during the first year after fertilizer application (i.e., July 2011 to July 2012). Of all Sedum spp., S. spurium was most prevalent within modules and best represented plant growth of any Sedum spp. in the current study. Therefore, height was measured for three representative $S$. spurium shoots per module. The dates of the first and last open flower per species per module were recorded to indicate bloom duration. Leaf tissue color was quantitatively evaluated at three locations within each module using a colorimeter (Minolta CR-310; Minolta Camera Co. Ltd., Osaka, Japan).

\section{Statistical analysis}

All data sets were analyzed using GraphPad Prism Version 5.03 software (GraphPad Software Inc., La Jolla, CA). One-way analysis of variance (ANOVA) was conducted for leachate chemical element amounts and concentrations, plant winter injury ranking, and bloom duration with differences among means determined using Tukey's multiple means comparison test. A two-way repeated measure ANOVA with a Bonferroni post-test was used to evaluate differences among treatments over time. Regression analyses were used to relate nutrient concentration, vegetative coverage, shoot height, and leaf color to fertilizer rate and to estimate regression parameters for the best-fit regression model (linear or quadratic). All data were evaluated using a significance level of $P<0.05$.

\section{Results and Discussion}

\section{Plant performance}

Overall appearance ranking, winter injury, and flowering. Green roof overall appearance evaluates visual plant performance, plant health, and green roof success (Clark and Zheng, 2012; Rowe et al., 2006). Winter injury is influenced by leaf desiccation and shoot dieback and may cause plant failure (Barker and Lubell, 2012). In addition, winter injury negatively impacts overall appearance and hinders plant performance, thus reducing green roof function. A high overall appearance and low winter injury is most desirable for green roofs.

Initial overall appearance (i.e., in July 2011) was not different among treatments. In 2012 , treatment $\left(\mathrm{F}_{9,20}=23.29, P<0.0001\right)$ and the interaction of treatment and time $\left(\mathrm{F}_{45,100}=2.40, P=0.0001\right)$ influenced overall appearance but not time alone $\left(\mathrm{F}_{5,100}=\right.$ $0.42, P=0.83)$. Winter injury differed among treatments when observed in Mar. 2012 $\left(\mathrm{F}_{9,29}=20.44, P<0.0001\right)$; however, no difference in winter injury was observed among fertilizer types. Brown, desiccated leaf tissue caused by winter injury was observed for the 30 and 60 treatments, resulting in a high winter injury ranking (Table 1). Boivin et al. (2001) also noted brown leaves resulting from winter injury for Sedum species. Winter injury impacted overall appearance, because leaf tissue damage was a main factor in a midlevel overall appearance ranking for the 60 treatment compared with all other treatments (Table 1). In the current study, overall appearance in the 60 treatment was among the highest in May and June 2012 after recovering from winter injury. However, in July 2012 , tall shoots in the 60 treatment fell over and exposed bare soil, which reduced overall appearance of the 60 compared with the 15 and 20 treatments. Tall shoots in high fertilizer treatments also had brown desiccated lower leaves, similar to observations by Barker and Lubell (2012). However, we observed adequate vegetative coverage within modules, which blocked the visibility of lower brown leaves in treatments of 30 or less. Thus, lower brown leaves did not negatively influence overall appearance in this study, similar to the results reported by Clark and Zheng (2012) but contrary to that reported by Barker and Lubell (2012). Despite winter injury, overall appearance of 30 , as well as 15 and 20, remained among the highest of all treatments at all time points in 2012 (Table 1). From Mar. to July 2012, the control had among the lowest overall appearance ranking (Table 1). In July 2012, the overall appearance of 15 was greater than 5 and the control; however, no significant improvement in overall appearance was observed for treatments greater than 15 (Table 1). Therefore, to avoid dieback of lower leaves and stems falling over, fertilization at rates of 15 or less are appropriate to ensure desirable overall appearance for this green roof system. Fertilizer types 5-Sus and 5-OR had among the lowest overall appearance rankings of all treatments from May to July 2012, but no difference between these two fertilizer types was observed.

Flowering (i.e., bloom duration) of all species was not significantly different among fertilizer treatments $\left(\mathrm{F}_{7,23}=1.28 ; P=0.32\right)$ or types $\left(\mathrm{F}_{3,11}=0.33, P=1.30\right)$ but ranged from $29.3 \pm 11.3 \mathrm{~d}$ in the control to $64.0 \pm 3.0 \mathrm{~d}$ in the 20 treatment $(\mathrm{n}=3$; Table 1$)$. Among species, $S$. spurium bloomed in more modules than S. ellacombianum, S. selskianum 'Goldilocks', S. reflexum 'Blue Spruce', or $S$. rupestre 'Angelina' [i.e., 26 vs. 16, 14, 10, and one module(s), respectively]. Bloom duration of $S$. spurium was also not significantly different among fertilizer treatments $\left(\mathrm{F}_{7,23}=1.31 ; P=0.31\right)$ or types $\left(\mathrm{F}_{3,11}=0.42\right.$, $P=0.74)$. S. spurium bloom duration ranged from $7.7 \pm 7.7$ to $40.0 \pm 4.4 \mathrm{~d}$ in the control and 10 treatments, respectively (Table 1). Further research is needed to identify factors influencing sedum flowering and determine the influence of fertilizer on bloom duration for individual sedum species or species combinations on a green roof. Besides contributing to visual appeal (Clark and Zheng, 2012), flowering of green roof plant species may provide additional ecological benefits in urban environments. Only during sedum flowering were pollinator insects, including bees, wasps, and flies, frequently observed on the rooftop. Pollinators were observed foraging for pollen from sedum flowers, both within and among modules. Although details of pollinator behavior and pollinator preferences among sedum species were not quantified, the ability of sedum to attract pollinators was clear. Green roofs have been identified as potentially valuable sites for bee conservation in urban areas (Tonietto et al., 2011). Further research is needed to evaluate how planting long-blooming sedum species or species mixes on green roofs impacts urban pollinator abundance, behavior, and health.

Vegetative coverage. Green roof performance is influenced by vegetative coverage, because a high coverage density shades the roof, resulting in low cooling costs for the building during the summer (Sailor, 2008). A high level of vegetative coverage is also recommended to suppress weeds (CookPatton and Bauerle, 2012; Snodgrass and Snodgrass, 2006).

Among treatments, vegetative coverage was significantly influenced by time $\left(\mathrm{F}_{4,80}=\right.$ $40.16, P<0.0001)$, treatment $\left(\mathrm{F}_{9,20}=3.28\right.$, $P=0.01)$, and the interaction of time and treatment $\left(\mathrm{F}_{36,80}=2.75, P<0.013\right)$. On 19 July 2011, the initial proportion vegetative coverage averaged $0.77 \pm 0.03$ for all treatments (Fig. 1). In Oct. 2011, vegetative coverage was greater for the 60 than all except the 15 and 7.5 treatments. By Mar. 2012 vegetative coverage of $60,30,20$, and 15 was greater than 5 and the control, and in Aug. 2012, coverage did not differ among treatments. Among fertilizer types, no difference in vegetative coverage was observed at any time point. We did not observe differences among treatments in weed suppression.

To determine the optimum fertilizer rate to maximize vegetative coverage, treatments 
showing high levels of winter injury (i.e., 30 and 60) were excluded. A fertilizer rate of $18.8 \mathrm{~g} \cdot \mathrm{m}^{-2} \mathrm{~N}$ was calculated to produce the greatest vegetative coverage after 1 year of growth following fertilization (i.e., Aug. 2012; Fig. 1). However, in Aug. 2012, all treatments including the control had a proportion vegetative coverage over 0.8 , indicating that in the first year after installation, no additional fertilizer was needed to ensure vegetative coverage above 0.8 in this green roof system. Although no fertilization was needed to maintain green roof coverage in the current study, fertilization in subsequent years may be required as substrate fertility declines (Rowe, 2011).

Plant growth. In addition to vegetative coverage, shoot height is an indicator of plant growth rate on green roofs (Snodgrass and Snodgrass, 2006). Many benefits of green roof plantings are achieved as a result of healthy plant growth (Dunnett and Kingsbury, 2008; Morgan et al., 2012). Flowering of green roof plants contributes to green roof aesthetic value and high visual appeal (Benvenuti and Bacci, 2010; Clark and Zheng, 2012) as well as providing food and habitat for pollinators in urban areas (Tonietto et al., 2011).

Shoot height for $S$. spurium was significantly influenced by time $\left(\mathrm{F}_{9,504}=7.27, P<\right.$ $0.0001)$, fertilizer treatment $\left(\mathrm{F}_{6,56}=176.69\right.$, $P<0.0001)$, and the interaction of time and fertilizer treatment $\left(\mathrm{F}_{54,504}=1.99, P<0.0001\right)$ for the duration of the study. Among time points, shoot height was taller for 2011 time points than observed in Mar. 2012, likely as a result of snow causing shoot compaction or shoots re-rooting when in contact with the growing substrate. By July 2012, an increase in shoot growth during the growing season would have caused taller shoots than observed in Mar. 2012. At individual time points, shoot height for $S$. spurium was not significantly different among treatments in Oct. 2011 and Mar. and May 2012. However, in July 2012, shoot height of 60 was taller than the control. Taller shoots for the 15 in July and Aug. 2011 and for the 10 in Sept. 2011 could have been caused by differences in fertilizer release, substrate heterogeneity among modules influencing fertility and plant growth, or morphological variability of $S$. spurium among modules. Regression analysis demonstrated a quadratic relationship $(\mathrm{Y}=5.98+0.10 \mathrm{X}-$ $\left.0.00098 \mathrm{X}^{2} ; R^{2}=0.48\right)$ between shoot height $(\mathrm{Y})$ and fertilizer rate $(\mathrm{X})$ for $S$. spurium in July 2012 (Fig. 2). No difference in shoot height for $S$. spurium was observed among fertilizer types. Although a higher fertilizer rate (i.e., 60) resulted in tall shoots, $S$. spurium had firm stems that remained upright until July 2012. By July 2012, tall, top-heavy stems in 60 fell over, potentially resulting from wind.

Leaf color. Leaf color influences green roof visual appeal with green leaves perceived as healthier than red or yellow leaves for sedum (Clark and Zheng, 2012).

Among all treatments, sedum leaf color was significantly influenced by time $\left(\mathrm{F}_{3,240}=\right.$ 331.86; $P<0.0001)$, treatment $\left(\mathrm{F}_{9,80}=3.66\right.$;

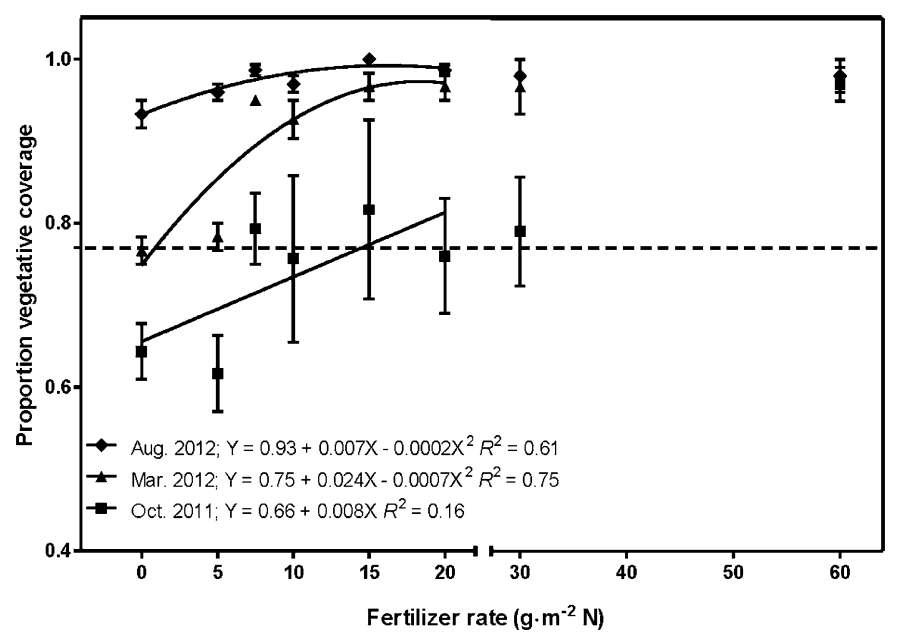

Fig. 1. Proportion vegetative coverage for sedum-vegetated green roof modules grown with no added fertilizer (control) or with fertilizer (i.e., $16 \mathrm{~N}-2.6 \mathrm{P}-10 \mathrm{~K}$ POLYON ${ }^{\circledR}$ Homogenous NPK plus Minors, 5-6 month controlled-release fertilizer) applied at rates of 5, 7.5, 10, 15, 20, 30, and $60 \mathrm{~g} \cdot \mathrm{m}^{-2}$ nitrogen (N) over the first growing season with respect to the mean initial (i.e., July 2011) coverage (dashed line). Values are means of three replications \pm SE. Where fertilizer treatment effects were significant $(P$ $<0.05)$, lines indicate the calculated regression. The regression line was excluded for the 30 and 60 treatments resulting from winter injury causing vegetative damage.

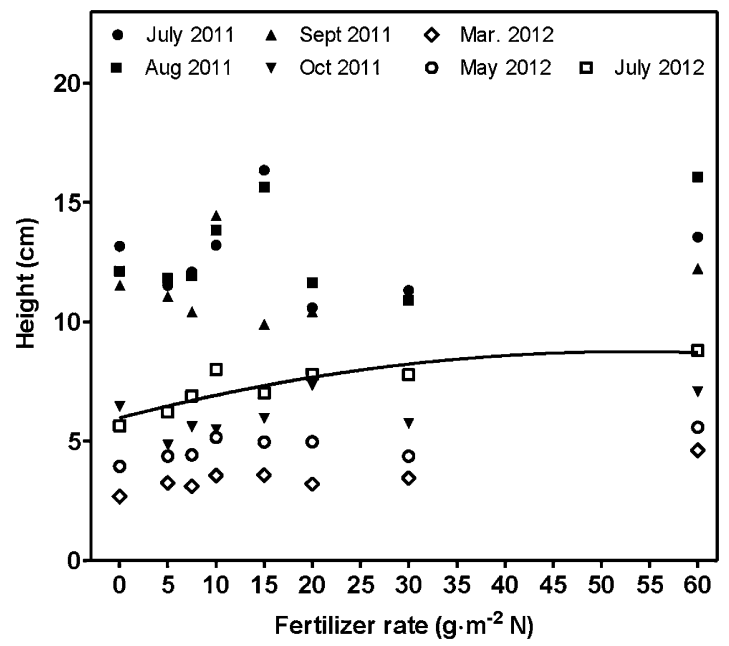

Fig. 2. Response of Sedum spurium shoot height to application rate of $16 \mathrm{~N}-2.6 \mathrm{P}-10 \mathrm{~K}$ POLYON ${ }^{\circledR}$ Homogenous NPK plus Minors, 5-6 month controlled-release fertilizer. Values are means of nine replications. Where the fertilizer application rate effect was significant $(P<0.05)$, a line indicates the calculated regression; otherwise, no lines are shown.

$P=0.0007)$, and the interaction $\left(\mathrm{F}_{27,240}=\right.$ 3.34; $P<0.0001)$ of time and treatment. In Sept. 2011, 60 had greener leaves than treatment 20 or lower (Fig. 3). In Mar. 2012, 20 had greener leaves than 60, 5, and the control. No significant difference in leaf color was observed among treatments in May 2012. Although leaf greenness was visually similar or greener in 30 and 60 than all other treatments in July 2012, measured greenness was lower for 60 than 7.5, 10, 15, and 20 and lower for 30 than 20. Low leaf greenness measurements for 30 and 60 in July 2012 might have been the result of tall plants causing measurement difficulties. For example, to measure leaf color for the 30 and 60 treatments, tall stems were compacted by the colorimeter plate, causing the color of stem tissue to be measured in addition to leaf color.
Because stem tissue was visually more red than leaf tissue, leaf color measurement of 30 and 60 likely reflected stem tissue color in combination with leaf color. Among time points, leaves were greener in Sept. 2011 vs. July 2012 for all treatments as well as in May 2012 vs. Mar. and July 2012 for all treatments. The occurrence of more yellow and red pigments in Mar. and July 2012 might have been the result of resource reallocation during cold or drought stress (Matile, 2000; Vollenweider and Gunthardt-Goerg, 2005). Among fertilizer types in Sept. 2011, leaves were greener for 5-Sus than 5 and the control; however, no difference among fertilizer types occurred for leaf color in Mar., May, or July 2012. The difference in leaf color between 5 -Sus and 5 after only 2 months was likely caused by nutrients being released faster, 


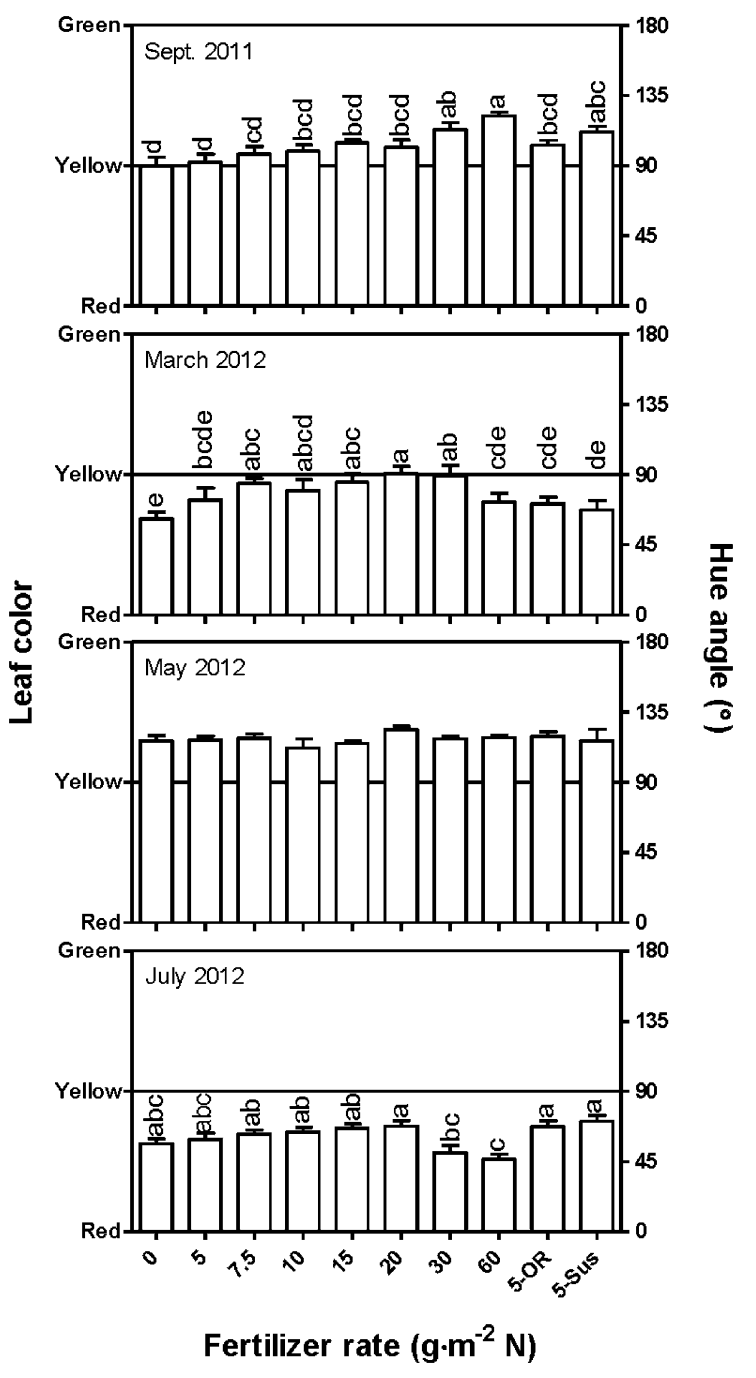

Fig. 3. Sedum leaf tissue hue angle relative to color following fertilization with $16 \mathrm{~N}-2.6 \mathrm{P}-10 \mathrm{~K}$ POLYON ${ }^{\circledR}$ Homogenous NPK plus Minors, 5-6 month controlled-release fertilizer [5, 7.5, 10, 15, 20, 30, and 60 $\mathrm{g} \cdot \mathrm{m}^{-2}$ nitrogen $\left.(\mathrm{N})\right], 4 \mathrm{~N}-4 \mathrm{P}-4 \mathrm{~K}$ Gaia Green All Purpose organic fertilizer (5-OR), or 2.9N-2.2P-2.3K fly-larvae processed chicken manure (5-Sus). Bars are means of nine replications + SE. Bars bearing the same letter are not significantly different at $P<0.05$ according to Tukey's multiple comparison test.

resulting in greater nutrient availability for sedum plants in 5-Sus than 5.

Differences in leaf color can influence both plant physiology and visual appeal. Physiologically, green leaves can have higher photosynthesis levels than red leaves (Gould et al., 2002), although we have not found results for sedum in the literature. Photosynthesis influences plant biomass, which affects the albedo and evapotranspiration rate for green roofs and ultimately the green roof functions of roof temperature mediation and water capture (Lundholm et al., 2010). However, we have found no studies quantifying the direct influence of sedum color on green roof performance. Qualitatively, sedum leaf color influences green roof visual appeal (Clark and Zheng, 2012) with green leaves resulting in a greater visual appeal than red or yellow leaves. Thus, leaf color is important to consider when implementing a green roof maintenance strategy to meet client preferences for visual appeal. Further research is needed to identify specific causes of leaf color change in sedum, the influence of environmental stresses on sedum leaf color, and the resulting green roof performance parameters after sedum leaf color changes.

Leachate $\mathrm{pH}$ and $\mathrm{EC}$. Leachate $\mathrm{pH}$ and EC measurements describe conditions in the ment. Leachate $\mathrm{pH}$ influences the nutrient availability for plant uptake (Zheng and Clark, 2013), whereas leachate EC reflects the nutrient concentration in the root zone (Jones, 2012).

Leachate $\mathrm{pH}$ was significantly influenced by time $\left(\mathrm{F}_{5,100}=38.83 ; P<0.0001\right)$ but not treatment $\left(\mathrm{F}_{9,20}=1.61 ; P=0.18\right)$ or the interaction between time and treatment $\left(\mathrm{F}_{45,100}=0.85 ; P=0.72 ;\right.$ data not shown $)$. Leachate $\mathrm{pH}$ ranged from $7.62 \pm 0.02$ in Aug. 2011 to $8.15 \pm 0.02$ in July 2012, which was greater than recommended for plant growth (i.e., 5.6 to 6.2 ; Reed, 1996) or specifically for sedum growth (i.e., 6.43 or lower; Zheng and Clark, 2013) in a soilless media. Leachate EC was significantly influenced by time growing substrate and root zone environ-
$\left(\mathrm{F}_{5,100}=19.94 ; P<0.0001\right)$, treatment $\left(\mathrm{F}_{9,20}=\right.$ 27.53; $P<0.0001)$, and the interaction between time and treatment $\left(\mathrm{F}_{45,100}=2.78\right.$; $P<0.0001$; data not shown). Leachate EC of 60 was greater than all other treatments in Aug. 2011 and Apr., June, and July 2012. In Oct. 2011, leachate EC of 30 was greater than all other CRF treatments. Among fertilizer types, leachate EC for 5-OR was greater than 5 and the control. However, by Aug. 2012, there were no significant differences in leachate EC among treatments. Fluctuations in leachate EC were observed over time for individual treatments. For 60 , leachate EC ranged from a high of $760.3 \pm 74.67 \mu \mathrm{S} \cdot \mathrm{cm}^{-1}$ in Oct. 2011 to $483.7 \pm 7.06 \mu \mathrm{S} \cdot \mathrm{cm}^{-1}$ in Aug. 2012. Leachate EC for the control changed from $278.0 \pm 11.24 \mu \mathrm{S} \cdot \mathrm{cm}^{-1}$ in Aug. 2011 to a high of $385.3 \pm 3.33 \mu \mathrm{S} \cdot \mathrm{cm}^{-1}$ in July 2012 . For some treatments, leachate EC was below the 600 to $2000 \mu \mathrm{S} \cdot \mathrm{cm}^{-1}$ range recommended by Wright (1986) for healthy and vigorous plant growth. Fluctuations in $\mathrm{pH}$ and EC could have been a result of variability in fertilizer release and plant uptake as a result of temperature or moisture fluctuations. Therefore, further research is needed to identify the EC range most appropriate for sedum growth as well as identifying how acidifying fertilizers can contribute to appropriate root zone $\mathrm{pH}$.

\section{Environmental impact}

Nutrient leaching. Environmental pollution can be prevented by applying appropriate fertilizer rates to avoid nutrient leaching from green roofs (Czemiel Berndtsson, 2010). Canadian federal and provincial water quality guidelines provide water quality target level thresholds (CCME, 2012; MOEE, 1994). Although nutrient levels in green roof runoff are not directly governed by these guidelines, they provide a benchmark that may prevent negative environmental impacts of green roof runoff (Van Seters et al., 2009).

Leachate from green roof modules contained no detectable $\mathrm{Al}, \mathrm{Cd}, \mathrm{Cr}, \mathrm{Hg}$, or $\mathrm{Pb}$; $\mathrm{Ni}$ and $\mathrm{Cu}$ were only detected in 60 in low amounts (i.e., a total of $4.11 \pm 0.06 \mathrm{mg}$ and $4.67 \pm 0.39 \mathrm{mg}$, respectively, over the whole study period). More $\mathrm{NH}_{4}{ }^{+}, \mathrm{NO}_{3}{ }^{-}, \mathrm{K}, \mathrm{Ca}, \mathrm{Mg}$, $\mathrm{S}, \mathrm{Na}$, and $\mathrm{Zn}$ were leached from 60 than all other treatments (Fig. 4A), whereas total leached $\mathrm{Fe}$ was only greater in 60 than 5 (Fig. 4B). Plant uptake of nutrients could have prevented leaching in treatments other than 60 or substrate nutrient levels could have been high and masked among-treatment effects (e.g., 930 ppm K). Only S, Fe, and Zn were leached in different amounts among CRF treatments less than 60 (Fig. 4B). Among fertilizer types, the total amount of $P$ leached for 5-Sus was greater than 5 and 5$\mathrm{OR}$ as well as some higher CRF rates (i.e., 7.5, 15, 20, and 30; Fig. 4B). Differences in nutrient analysis ratios among fertilizer types (Table 1) indicate more $\mathrm{P}$ was applied for 5 Sus than 5 or 5-OR. For 5-Sus, P provided by fertilizer in addition to $\mathrm{P}$ provided by the substrate likely resulted in higher $\mathrm{P}$ supplied than was required for plant growth. Total 
A

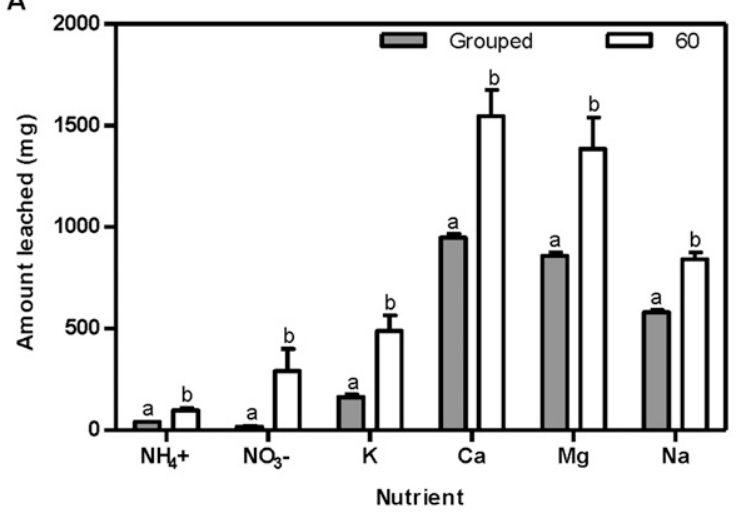

B

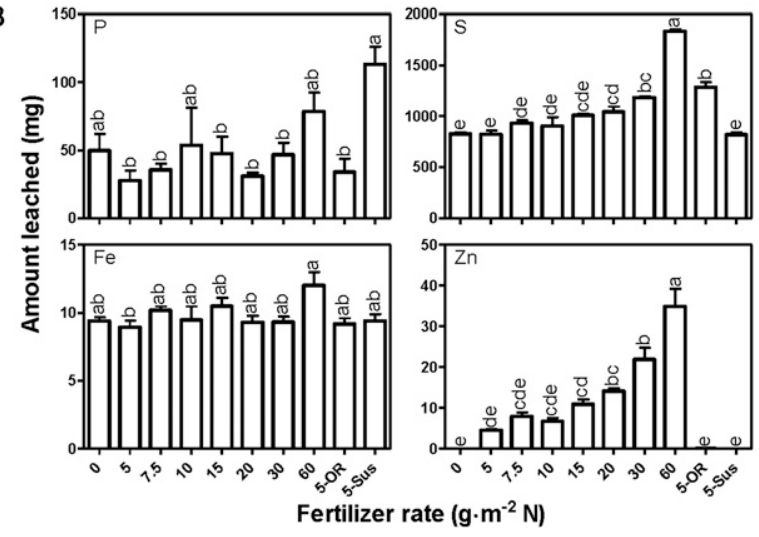

Fig. 4. Total nutrients leached from sedum-vegetated green roof modules between 15 July 2011 and 16 Aug. 2012 among individual (clear bars; $n=3$ ) or grouped (shaded bars; $n=27$ ) treatments fertilized with rates of $16 \mathrm{~N}-2.6 \mathrm{P}-10 \mathrm{~K}$ POLYON ${ }^{\circledR}$ Homogenous NPK plus Minors, 5-6 month controlledrelease fertilizer, $4 \mathrm{~N}-4 \mathrm{P}-4 \mathrm{~K}$ Gaia Green All Purpose organic fertilizer (5-OR), or 2.9N-2.2P-2.3K flylarvae processed chicken manure (5-Sus). A grouped mean was presented for nutrients with no difference among the majority of treatments (A), whereas differences among all treatments were presented for phosphorus $(\mathrm{P})$, sulfur $(\mathrm{S})$, iron $(\mathrm{Fe})$, and zinc $(\mathrm{Zn})(\mathbf{B})$. Bars represent the mean $+\mathrm{se}$. Bars bearing the same letter are not significantly different at $P<0.05$ according to Tukey's multiple comparison test.

leached $\mathrm{S}$ differed among fertilizer types with 5-OR leaching more $\mathrm{S}$ than 5, 5-Sus, and the control (Fig. 4B). Considering the full elemental composition of a fertilizer in combination with the growing substrate may prevent overapplication of individual elements. Czemiel Berndtsson et al. (2009) found green roof substrate influenced the amount of $\mathrm{P}$ leached from an extensive green roof system and reported $\mathrm{Zn}$ present in green roof leachate.

Thresholds of elemental concentrations have been set for $\mathrm{NO}_{3}{ }^{-}$in Canada (CCME, 2012) and for $\mathrm{P}, \mathrm{Fe}, \mathrm{Zn}$, and $\mathrm{Cu}$ in Ontario (MOEE, 1994). Although green roof leachate is not governed by these thresholds, we found although leachate $\mathrm{NO}_{3}{ }^{-}$concentration was higher for 60 than all other treatments, it was still below the threshold (Fig. 5). Leachate P concentration was greater than the threshold for all treatments, whereas leachate $\mathrm{Zn}$ concentration was only greater than the threshold for fertilized treatments. Both leachate $\mathrm{Fe}$ and $\mathrm{Cu}$ concentrations for 60 were greater than the thresholds. The relationships between leachate nutrient concentration and CRF fertilizer rate shown in Figure 5 indicate that low fertilizer rates (i.e., less than 20 $\mathrm{g} \cdot \mathrm{m}^{-2} \mathrm{~N}$ ) were appropriate for $\mathrm{NO}_{3}{ }^{-}$and $\mathrm{Cu}$, and there was incremental over-application of $\mathrm{P}, \mathrm{Fe}$, and $\mathrm{Zn}$ with increasing fertilizer rates. No difference in leachate $\mathrm{NO}_{3}{ }^{-}$concentration was observed for treatments of 20 or less, including the control, indicating fertilization at rates over 20 exceeds plant demand for $\mathrm{NO}_{3}{ }^{-}$. High $\mathrm{P}$ concentration in the substrate, combined with added $\mathrm{P}$ during fertilization, may have caused high leachate $\mathrm{P}$ concentrations for all treatments. These results build on the study by Van Seters et al. (2009), which also measured high $P$ concentrations from green roof runoff in excess of the Ontario guideline threshold. Similarly, we found high concentrations of $\mathrm{Zn}$ and $\mathrm{Fe}$ in leachate, which may have been caused by fertilizer over-application, compared with the needs of the vegetation. We have not found reports of micronutrient requirements for sedum in the literature and therefore suggest further research in this direction.

Among fertilizer types, leachate $\mathrm{Zn}$ concentration was above the threshold for 5 but below for 5-OR and 5-Sus. $\mathrm{NO}_{3}{ }^{-}, \mathrm{Fe}$, and $\mathrm{Cu}$ concentrations were below the threshold for all fertilizer types (data not shown). Therefore, fertilizer rate and type should be considered in combination with the green roof substrate to prevent excess nutrient leaching. Further research is needed for other green roof systems (i.e., substrate and fertilizer combinations) to determine appropriate, but not excess, fertility rates for green roof plants. In addition, because green roof systems can be highly variable, further research is needed to develop site-specific fertilization protocols and encouragement is needed to implement fertilization recommendations within the green roof industry.

\section{Conclusion}

An appropriate fertilizer rate for green roof maintenance should not cause leachate nutrient amounts to exceed those of the control or cause leachate nutrient concentrations to surpass legislated water quality thresholds. In addition, an appropriate fertilizer rate should provide adequate nutrition for plant growth to sustain green roof coverage and overall visual appeal. We found the total amount $(\mathrm{mg})$ leached for most nutrients in treatments from 5 to 30 did not differ from the control; however, only at rates from 5 to 15 and 5 to 10 were leachate $\mathrm{S}$ and $\mathrm{Zn}$ amounts no different from the control, respectively. Concentrations of $\mathrm{NO}_{3}{ }^{-}, \mathrm{Fe}$, and $\mathrm{Cu}$ in treatments from 5 to 20 were not different from the control and were below water quality thresholds (CCME, 2012; MOEE, 1994). All P concentrations were above the threshold and treatments from 5 to 30 did not differ from the control. Concentration of $\mathrm{Zn}$ in treatments from 5 to 15 did not differ from the control; however, all were greater than the threshold. For plant growth, we found both root zone $\mathrm{pH}$ and $\mathrm{EC}$ in treatments from 5 to 30 , and winter injury in treatments from 5 to 20 , did not differ from the control. Overall appearance was among the highest for 15 and 20 throughout 2012, and vegetative coverage was calculated to peak at $18.8 \mathrm{~g} \cdot \mathrm{m}^{-2} \mathrm{~N}$. From these results we can conclude that, although fertilizing at $18.8 \mathrm{~g} \cdot \mathrm{m}^{-2} \mathrm{~N}$ may maximize vegetative coverage, amount of $\mathrm{S}$ and $\mathrm{Zn}$ leached would be greater than the control, and $\mathrm{Zn}$ concentration would exceed water quality thresholds (MOEE, 1994). Alternatively, fertilizing at $15 \mathrm{~g} \cdot \mathrm{m}^{-2} \mathrm{~N}$ would appropriately lower the amount of $\mathrm{S}$ and $\mathrm{Zn}$ leached from this green roof system, retain a high overall appearance rating, and only slightly reduce the vegetative coverage based on observations in this study. However, by fertilizing at a rate of $10 \mathrm{~g} \cdot \mathrm{m}^{-2} \mathrm{~N}$, the amount of $\mathrm{Zn}$ leached would not differ from the control. Although given the small difference in amount of $\mathrm{Zn}$ leached between the 10 and 15 treatments over 1 year of growth (i.e., 4.3 $\mathrm{mg}$ ), plant growth benefits justify fertilizing at 15 rather than $10 \mathrm{~g} \cdot \mathrm{m}^{-2} \mathrm{~N}$. Therefore, to maintain plant growth without negative environmental effects from leached nutrients, we recommend fertilizing sedum-vegetated green roof modules with $15 \mathrm{~g} \cdot \mathrm{m}^{-2} \mathrm{~N} \mathrm{CRF}$ with a low $\mathrm{Zn}$ concentration in addition to lowering the substrate $\mathrm{P}$ concentration and reducing the rate of $\mathrm{P}$ applied.

Among three fertilizer types applied at 5 g. $\mathrm{m}^{-2} \mathrm{~N}$ (i.e., $5 \mathrm{CRF}, 5-\mathrm{OR}$, and 5-Sus) and the control, we found the majority of nutrients 


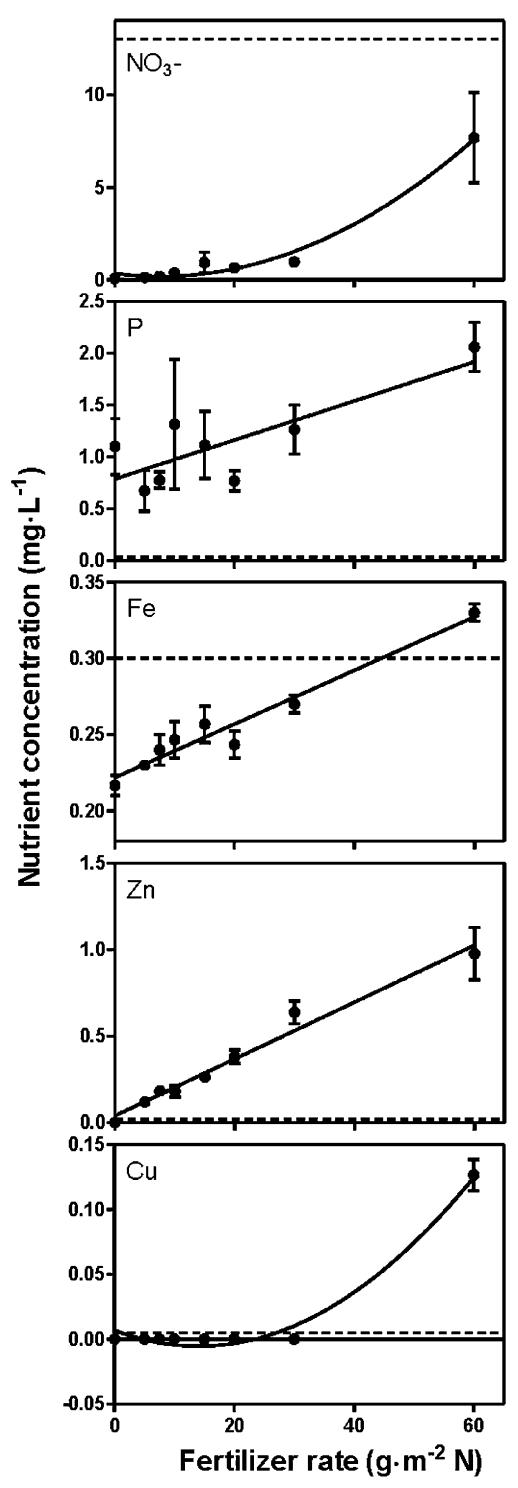

Fig. 5. Leachate nutrient concentration from volume-weighted samples collected between 15 July 2011 and 16 Aug. 2012 from sedumvegetated green roof modules fertilized with 0 , $5,7.5,10,15,20,30$, and $60 \mathrm{~g} \cdot \mathrm{m}^{-2}$ nitrogen $(\mathrm{N})$ of $16 \mathrm{~N}-2.6 \mathrm{P}-10 \mathrm{~K}$ POLYON ${ }^{\circledR}$ Homogenous NPK plus Minors, 5-6 month controlledrelease fertilizer. Values are means of three replications \pm SE. Where fertilizer application rate effects were significant $(P<0.05)$, lines indicates the calculated regression. Dashed lines mark the upper threshold to meet Canadian (i.e., $\mathrm{NO}_{3}^{-}$; $\mathrm{CCME}, 2012$ ) and Ontario [i.e., phosphorus $(\mathrm{P})$, iron $(\mathrm{Fe})$, zinc $(\mathrm{Zn})$, and copper $(\mathrm{Cu})$; MOEE, 1994] water quality objectives.

did not differ in amount or concentration leached. However, the amount and concentration of $\mathrm{P}$ leached for 5-Sus was greater than 5 and 5-OR but not the control. The amount of $\mathrm{S}$ leached was higher for 5-OR than 5, 5-Sus, and the control. Leachate $\mathrm{NO}_{3}{ }^{-}$, $\mathrm{Fe}$, and $\mathrm{Cu}$ concentrations were below the water quality thresholds (MOEE, 1994) for all fertilizer types, whereas leachate $\mathrm{Zn}$ concentration was above the threshold for 5 but below for 5-OR and 5-Sus. Therefore, when testing fertilizer types for green roofs, the composition of all nutrients needs to be considered. Comparing plant growth among fertilizer types, we found no difference among leachate pH and EC, winter injury, overall appearance, shoot height, or bloom duration for 5 or the control. Vegetative coverage of 5-Sus was only greater than 5 and the control in Mar. 2012, and leaf greenness was only greater for 5-Sus than 5 in Sept. 2011. From these results, 5-OR fertilization may not be appropriate in combination with the green roof substrate used in this study, because plant growth did not benefit from 5-OR application compared with 5 . In addition, because more $\mathrm{S}$ was leached from 5-OR than the control, this fertilizer type is not well suited for the green roof system used in this study. Although higher $\mathrm{P}$ was leached from 5-Sus than the control, 5-Sus provided the added plant growth benefits of increased coverage the first spring and increased greenness soon after application compared with the CRF. From these results, we conclude that fertilizing with 5-Sus, when using a substrate with low $\mathrm{P}$, would be preferred to CRF as a result of the plant growth benefits provided. In addition, 5-Sus can be locally produced and diverts waste from the poultry industry, thereby offering a sustainable solution for supplementing green roof plant nutrition. Further study is needed to evaluate the timing of 5-Sus nutrient release and plant growth response to higher rates of 5-Sus (i.e., 15 $\mathrm{g} \cdot \mathrm{m}^{-2} \mathrm{~N}$ ) in this and other green roof systems.

Overall, fertilization of green roof modules can be adopted as a standard green roof maintenance procedure without negatively impacting environmental water quality if appropriate fertilizer rates and types are used in accordance with the nutrient composition of the substrate. However, discretion should be used, because nutrient leaching is influenced by the nutrient amount and concentration in the substrate as well as by the applied fertilizer.

\section{Literature Cited}

Barker, K.J. and J.D. Lubell. 2012. Effects of species proportions and fertility on Sedum green roof modules. HortTechnology 22:196-200.

Benvenuti, S. and D. Bacci. 2010. Initial agronomic performances of Mediterranean xerophytes in simulated dry green roofs. Urban Ecosyst. 13:349-363.

Boivin, M.A., M.P. Lamy, A. Gosselin, and B. Dansereau. 2001. Effect of artificial substrate depth on freezing injury of six herbaceous perennials grown in a green roof system. HortTechnology 11:409-412.

CCME. 2012. Canadian water quality guidelines for the protection of aquatic life: Nitrate. In: Canadian environmental quality guidelines. Canadian Council of Ministers of the Environment, Winnipeg, Canada.

Chen, J., Y. Huang, and R.D. Caldwell. 2001. Best management practices for minimizing nitrate leaching from container-grown nurseries. In Optimizing nitrogen management in food and energy production and environmental protection: Proceedings of the $2^{\text {nd }}$ international nitrogen conference on science and policy. Sci. World 1(suppl 2):96-102.
Clark, M.J. and Y. Zheng. 2012. Evaluating fertilizer influence on overwintering survival and growth of Sedum species in a fall-installed green roof. HortScience 47:1-7.

Cook-Patton, S.C. and T.L. Bauerle. 2012. Potential benefits of plant diversity on vegetated roofs: A literature review. J. Ecol. Mgt. 106: 85-92.

Currie, B.A. and B. Bass. 2008. Estimates of air pollution mitigation with green plants and green roofs using the UFORE model. Urban Ecosyst. 11:409-422.

Czemiel Berndtsson, J. 2010. Green roof performance towards management of runoff water quantity and quality: A review. Ecol. Eng. 36:351-360.

Czemiel Berndtsson, J., L. Bengtsson, and K. Jinno. 2009. Runoff water quality from intensive and extensive green roofs. Ecol. Eng. 35:369-380.

Dunnett, N. and N. Kingsbury. 2008. Planting green roofs and living walls. Timber Press, Portland, OR.

Emilsson, T., J. Czemiel Berndtsson, J.E. Mattsson, and K. Rolf. 2007. Effect of using conventional and controlled release fertilizer on nutrient runoff from various vegetated roof systems. Ecol. Eng. 29:260-271.

FLL. 2008. Guidelines for the planning, construction, and maintenance of green roofing - Green roofing guideline. Forschungsgesellschaft Landschaftsentwicklung Landschaftsbau, Bonn, Germany.

Gould, K.S., T.C. Vogelmann, T. Han, and M.J. Clearwater. 2002. Profiles of photosynthesis within red and green leaves of Quintinia serrata. Physiol. Plant. 116:127-133.

Green Roofs for Healthy Cities. 2012. Annual green roof industry survey for 2011. $7 \mathrm{Feb}$. 2013. <http://chesapeakestormwater.net/wpcontent/uploads/downloads/2012/05/2012 GreenRoofIndustrySurvey.pdf $>$.

Gregoire, B.G and J.C . Clausen. 2011. Effect of a modular extensive green roof on stormwater runoff and water quality. Ecol. Eng. 37:963969.

Jones, J.B., Jr. 2012. Plant nutrition and soil fertility manual. 2nd Ed. CRC Press, Boca Raton, FL.

Lundholm, J., J.S. MacIvor, Z. MacDougall, and M. Ranalli. 2010. Plant species and functional group combinations affect green roof ecosystem functions. PLoS One 5:E9677.

Matile, P. 2000. Biochemistry of Indian summer: Physiology of autumnal leaf coloration. Exp. Gerontol. 35:145-158.

MOEE. 1994. Water management policies: Provincial water quality objectives. Queen's Printer for Ontario.

Moran, A.C. 2004. A North Carolina field study to evaluate green roof runoff quantity, runoff quality, and plant growth. MS thesis. North Carolina State University, Department of Biological and Agricultural Engineering, Raleigh, NC.

Morgan, S., S. Celik, and W. Retzlaff. 2012. Green roof storm-water runoff quantity and quality. $\mathrm{J}$. Environ. Eng. 139:471-478.

Oberndorfer, E., J. Lundholm, B. Bass, R.R. Coffman, H. Doshi, N. Dunnett, S. Gaffin, M. Kohler, K. Liu, and B. Rowe. 2007. Green roofs as urban ecosystems: Ecological structures, functions, and services. Bioscience 57:823-833.

Reed, D.W. 1996. A grower's guide to water, media, and nutrition for greenhouse crops. Ball Publishing, Batavia, IL.

Retzlaff, B., J. Gibbs-Alley, L. Swearingin, S. Morgan, V. Jost, and K. Luckett. 2009. 
Fertility options for green roofs. Proc. of Greening Rooftops for Sustainable Communities, Atlanta, GA.

Retzlaff, W., S. Ebbs, S. Alsup, S. Morgan, E. Woods, V. Jost, and K. Luckett. 2008. What is that running off my green roof? Proc. Green Roofs for Healthy Cities, Greening Rooftops for Sustainable Communities Conference, Baltimore, MD.

Rowe, D.B. 2011. Green roofs as a means of pollution abatement. Environ. Pollut. 159: 2100-2110.

Rowe, D.B., M.A. Monterusso, and C.L. Rugh. 2006. Assessment of heat-expanded slate and fertility requirements in green roof substrate. HortTechnology 16:471-477.
Sailor, D.J. 2008. A green roof model for building energy simulation programs. Energy Build. 40:1466-1478.

Snodgrass, E.C. and L.L. Snodgrass. 2006. Green roof plants: A resource and planting guide. Timber Press, Portland, OR.

Tan, P.Y. and A. Sia. 2009. Understanding the performance of plants on non-irrigated green roofs in Singapore using a biomass yield approach. Nat. Singapore. 2:149-153.

Tonietto, R., J. Fant, J. Ashcher, K. Ellis, and D. Larkin. 2011. A comparison of bee communities of Chicago green roofs, parks, and prairies. Landsc. Urban Plan. 103:102-108.

Van Seters, T., L. Rocha, D. Smith, and G. MacMillan. 2009. Evaluation of green roofs for runoff retention, runoff quality, and leachability. Water Qual. Res. J. Canada 44: 33-47.

Vollenweider, P. and M.S. Gunthardt-Goerg. 2005. Diagnosis of abiotic and biotic stress factors using the visible symptoms in foliage. Environ. Pollut. 137:455-465.

Wolf, D. and J.T. Lundholm. 2008. Water uptake in green roof microcosms: Effects of plant species and water availability. Ecol. Eng. 33:179-186.

Wright, R.D. 1986. The pour through nutrient extraction procedure. HortScience 21: 227-229.

Zheng, Y. and M.J. Clark. 2013. Optimal growing substrate $\mathrm{pH}$ for five Sedum species. HortScience 48:448-452. 